4. Пискунова Е. В. Зарубежный опыт в организации инновационных образовательных программ [Електронний ресурс] / Е.В.Пискунова // Universum: Вестник Герценовского университета. - 2007. - №1. - C. 19-21. - Режим доступу: http://cyberleninka.ru/ article/n/zarubezhnyy-opyt-realizatsii-innovatsionnyh-obrazovatelnyh-programm $\quad \mathbf{5}$. Положення про проведення практики студентів вищих навчальних закладів України: наказ Міністерства освіти України № 93 від 8 квітня 1993 року. 6. Усеінова Л. Ю. Формування професійнопрактичної компетентності майбутніх інженерів-педагогів в умовах виробничої практики : автореф. дисертації на здобуття наук. ступеня канд. пед. наук / Л. Ю. Усеінова. - Київ, 2010. 7. Хорошун К. В. Подготовка студентов инженерного вуза к производственной практике на основе информационных технологий / К. В. Хорошун // Вестник Московского государственного гуманитарного университета им. М. А. Шолохова. Педагогика и психология. - 2014. - № 1. - С. 80-84. 8. A White Paper: The Case for Virtual Internship [Електронний ресурс]. - Режим доступу: http://efficient-enterprises.s3.amazonaws.com/virtualinternship-white-paper/virtual-internship-white-paper.pdf 9. Career Development Center [Електронний ресурс]. - Режим доступу: http://career.uark.edu 10. Career development manual. Tennessee State University [Електронний pecypc]. - Режим доступу: http://www.tnstate.edu/careers/TennSt_CDM_12-13_Online.pdf 11. Career management system for Loyola students and graduates [Електронний pecypc].- Режим доступу: https://luccsm.symplicity.com/students/ 12. Harvard NIEHS Center for Environmental Health [Електронний peсурс]. - Режим доступу : http://www.hsph.harvard.edu/niehs/career-development/ 13. Standford Career Development Center [Електронний pecypc].- Режим доступу : https://careers.stanford.edu/ 14. What is an «internship»? [Електронний ресурс].- Режим доступу: http://polisci.osu.edu/sites/polisci.osu.edu/ files/What\%20is\%20an\%20Internship.pdf

УДК $37.014(430)$

Ірина Селищева

\title{
ІСТОРИЧНА ОСВІТА В ЗАГАЛЬНООСВІТНІХ ШКОЛАХ НІМЕЧЧИНИ
}

Селищева I. А. Історична освіта в загальноосвітніх школах Німеччини.

У статті розглядаються загальні підходи до історичної освіти в загальноосвітніх школах Німеччини в контексті вимог Ради Європи та з урахуванням національних традицій. 3 огляду на мету сучасної історичної освіти, сформульованої EUROCLIO, визначено ті питання, які нині залишаються відкритими і потребують розв'язання.

Ключові слова: історична освіта, підходи до навчання історії, зміст освіти, історичне критичне мислення.

Селищева И. А. Историческое образование в общеобразовательных школах Германии.

В статье рассматриваются общие подходы к историческому образованию в средних школах Германии в контексте требований Совета Европы и с учетом национальных традиций. Принимая во внимание цель современного исторического образования, сформулированную EUROCLIO, определены те вопросы, которые на сегодня остаются открытыми и требуют внимания.

Ключевые слова: историческое образование, подходы к обучению истории, содержание образования, историческое критическое мышление.

Selyshcheva I. A. History education at public schools in Germany. 
This article discusses general approaches to history education at secondary schools in Germany according to the requirements of the Council of Europe in view of national traditions. The key and urgent issues have been outlined with a view of the goal of contemporary history education formulated by EUROCLIO.

Key words: history education, approaches to teaching history, content of education, historical critical thinking.

Історія та суспільствознавство як дисципліни завжди були компонентом навчальних планів як у середній, так і у вищій освіті будь-якої країни. Свого часу У. Черчилль пояснив важливість знань історії громадянами влучним висловом: «Народ, що не знає своєї історії, не має права на майбутнє». Знання історії власного народу є одним із чинників формування національної ідентичності особи, але знання інших дисциплін соціально-гуманітарного циклу, які є ядром історичної освіти, а саме: всесвітньої історії й суспільствознавства, $є$ надзвичайно важливими для формування світогляду особистості. Саме тому Державний стандарт базової і повної загальної середньої освіти містить як складник розділ «Освітня галузь «Суспільствознавство», який охоплює історичний та суспільствознавчий компоненти.

У процесі вивчення історії та суспільствознавства відбувається формування громадянської позиції учнів, і нині, у контексті подій в Україні, відчувається потреба у формуванні сталих гуманістичних переконань, які могли б протидіяти пропаганді та різного роду впливам на свідомість. Досягти успіху можна лише через створення виважених та ефективних механізмів патріотичного виховання, однак питому вагу в цій справі матимуть як раз знання історії та основ суспільствознавства. Тому проблема навчання історії i суспільствознавства в Україні, вивчення досвіду інших країн у цій галузі є актуальними і потребують особливої уваги науковців. Німеччина, яка, попри негативний імідж країниагресора у Другій світовій війні та поділ держави на дві країни 3 контроверсійними ідеологіями, протягом другої половини ХХ-го століття створила умови для появи громадянського суспільства зі сталими гуманістичними переконаннями, тому досвід історичної освіти ФРН і було обрано для аналізу.

Проблема історичної освіти та ії різних аспектів $є$ однією з актуальних у науковому педагогічному просторі України. Дослідження вітчизняних науковців присвячено різним аспектам історичної освіти. Серед дослідників слід назвати К. Баханова, О. Костенко, В. Кравця, О. Токмаченко, О. Пометун та інших. Вивченням досвіду Німеччини у питаннях історичної освіти приділили увагу К. Бергман, А. Еккер, М. Захсе, П. Карстен, Й. ван дер Лью-Роорд, П. Полянський, А. Сахновський, Р. Страдлінг. Проте, незважаючи на наявність публікацій з проблем історичної освіти, зіставного аналізу практики навчання історії у ФРН у нових суспільно-політичних умовах, як і змісту історичної освіти не здійснювалося.

Mema cmammi - вивчити загальні підходи до навчання історичних дисциплін у школах ФРН у контексті вимог Ради Свропи та з урахуванням національних традицій.

Історична освіта в радянську добу була, як відомо, не просто дисципліною, вона слугувала засобом маніпуляції свідомістю громадян, формування так званого «правильного бачення» місця СРСР у системі глобальної політики. Тому важко переоцінити важливість фактичних, i, головне, об'єктивних знань про закономірності державного і суспільного розвитку. Саме вони є фундаментом формування патріотично налаштованого громадянина, політично й соціально ангажованої особистості. Тому питанням історичної освіти у ФРН приділяється багато уваги, попри відмінності в загальних підходах й організації навчального процесу. 
Особливістю системи освіти ФРН, яка має власні традиції історичної освіти, але намагається дотриматися відповідності загальноєвропейським стандартам, є її автономність i, відповідно, неоднаковість змісту навчання та суто методичних підходів до викладання на різних етапах шкільної освіти. Кожна федеральна земля на власний розсуд приймає рішення щодо визначення змісту освіти й організації навчального процесу, але є певні спільності в загальних підходах до викладання історії та суспільствознавчих дисциплін через загальну мету історичної освіти.

Вивчення історії розпочинається ще у межах початкової освіти, де історичні знання певною мірою інтегровані до змісту інших курсів, а саме: до курсів біології, географії, фізики. На першому ступені шкільної освіти протягом років вивчається курс історії як самостійної дисципліни. На старшому ступені шкільної освіти вивчення історії продовжується, а в деяких, переважно у профільних школах, історія пропонується додатково також як факультатив.

Специфічною є і дидактика історичних дисциплін у Німеччині. Так, М. Заксе, радник Державного інституту шкільної педагогіки та освітніх досліджень (м. Мюнхен), стверджує, що в межах шкільної освіти дидактика історії спрямована на активізацію самостійної пізнавальної діяльності учнів, насамперед учнів старшої школи. Саме тому акцентується увага на проведенні тематичних досліджень і виконанні проектів. Відмінною рисою навчання історії $є$ спонукання до самостійної класифікації учнями історичного розвитку на основі аналізу документів та узагальнення різних фактів минулого. Учителі, зі свого боку, мають підтримувати тісний взаємозв'язок історичної науки 3 освітнім процесом i демонструвати «суперечливість історії щодо суб'єктивних та ідеологічних думок» [1, с. 1]. Наголошується на тому, що зміст навчання постійно оновлюється, а метою сучасних уроків історії є не глибокі знання історії заради власне знань, а формування трьох компетентностей: компетентності у предметі: тверді знання (історичні факти, особи, ідеї, події, історичний розвиток (періодизація регіональної, національної, європейської, всесвітньої історії), аспекти політичного, соціального, культурного розвитку; компетентності в навичках й уміннях: уміння надавати історичного значення часовим i просторовим контекстам, володіння історичною термінологією, уміння розрізняти історичні джерела від історичних описів i нарисів, уміння опрацьовувати джерела рідною та іноземною мовами, використовувати новітні технології та репрезентувати результати навчальної діяльності; особистісносоиіальна компетенція: позитивна налаштованість, толерантність, повага до інакшості, відкритість, готовність до активної участі в державному й суспільному житті, готовність до діалогу.

Серед нових орієнтирів під час викладання дисциплін історичного блоку очевидною є мета - розвинути уміння розглядати суперечливі питання щодо національної, групової або власної ідентичності, уміння 3 різних позицій аналізувати та інтерпретувати події та історичні явища, залучаючи у процес аналітичної обробки погляди різних істориків на них, уміння використовувати навчальні можливості різних дисциплін у позашкільній роботі у процес вивчення історії [1, с. 2-3].

Зміст історичної освіти у ФРН відрізняється тим, що формується і викладається не тільки оглядово (країна - період - події), з позиції хронології подій, але й на основі підходу, який має назву «горизонтальна перспектива». Особливість такого підходу полягає у повторенні важливого змісту під іншим поглядами, відповідно до віку учнів та розуміння ними подій минулого з урахуванням набутого досвіду. Такий формат вивчення історії, на думку М. Заксе, мав би посприяти формуванню в учнів умінь розглядати суперечливі 
питання, аналізувати й інтерпретувати події або історичні явища самостійно, спираючись на різні погляди істориків, та формувати власні думки щодо подій у процесі роботи з фактами та свідченням. Саме тому німецькі підручники 3 історії обов'язково містять уривки ключових документів, статей, інформативних листів, які підтверджують основні положення, викладені в розділі підручника.

Німеччина приділяє велику увагу історичній освіті учнів. Викладання дисциплін історичного блоку відбувається 3 урахуванням загальноєвропейських тенденцій та відповідно до вимог Ради Європи. Так, усвідомлення важливості знання історії стало поштовхом до того, що у європейських країнах, у тому числі й у ФРН, з ініціативи Ради Європи було створено організації вчителів і викладачів історичних дисциплін на національному рівні. У 1992 р. у Страсбурзі делегати долучилися до створення нового загальноєвропейського координаційного органу- Європейської постійної конференції асоціації викладачів історії, яка пізніше отримала назву EUROCLIO [2].

Одним із ключових завдань організації $\epsilon$ розвиток широкої «європейської поінформованості через викладання історії з урахуванням глобальних, національних та регіональних вимірів; сприяння миру, стабільності і демократії за допомогою поширення правдивого викладання історії» [2], сприяння формуванню в учнів критичного світогляду.

Оволодіння навичками історичного критичного мислення, як провідне завдання історичної освіти, ускладнюється на практиці цілою низкою обставин. Насамперед ідеться про перевантаження курсів історії вже на рівні шкільної освіти величезними обсягами історичної інформації, яку мають засвоїти учні, що фактично не залишає часу на практичне застосування знань та розвиток історичного мислення [3]. Тож визначення змісту історичної освіти є нині однією 3 проблем, яка залишається не розвязаною, як i розроблення підручників, які б ураховували багатоперспективний підхід в освіті.

Науковці окреслили напрямки реформування історичної освіти: залучення до навчального процесу порівняльної історії, використання новітніх досліджень не тільки історичної науки, а й суміжних 3 історією дисциплін, викладання історії 3 пропозицією різноманітних перспектив [3].

Підсумовуючи, наголосимо на тому, що історична освіта в Німеччині перебуває під впливом загальноєвропейських тенденцій і прагне, з урахуванням національних традицій у викладанні, має місце імплементація у практику вимог Ради Європи. Основна увага приділяється формуванню в учнів критичного історичного мислення на основі засвоєння фактичного матеріалу під час роботи з історичними документами, матеріалами досліджень істориків, які мають контроверсні погляди на події, що спонукатиме до формування власного бачення історичних подій і постатей.

Основним підходом є багатоперспективність в освіті, але проблемними залишаються питання формування виваженого змісту історичної освіти та розроблення навчальних матеріалів.

Ці проблеми є актуальними і для освітньої системи України. Ключовою для національної системи історичної освіти залишається проблема маніпуляцій фактами історії для формування певного бачення минулого, а у ФРН, як і в більшості європейських країн, ця проблема є розв'язаною. Подальшого вивчення потребують саме питання формування змісту історичної освіти та підходів до викладання історії.

\section{Література}

1. Заксе М. Вивчення історії у старшій профільній школі на прикладі Німеччини [Електронній ресурс] / М. Захсе. - Режим доступу: http://www.novadoba. org.ua/ ukr/node/60 
2. Лью-Роорд Й. ван дер. EUROCLIO - 10 років роботи над вивченням і викладанням історії [Електроннй $\quad$ ресурс] / Йоке ван дер Лью-Роорд. - Режим доступу: http://www.novadoba.org.ua/ukr/node/54 3. Страдлінг Р. Проблеми викладання історії у XXI столітті [Електроннй ресурс]/ P. Страдлінг. - Режим доступу: http://www.novadoba.org.ua/ukr/node/53

УДК 37.(091)

Олена Устименко-Косоріч

\title{
ТИПИ БАЯННО-АКОРДЕОННОЇ ШКОЛИ В СИСТЕМІ МУЗИЧНОЇ ОСВІТИ СЕРБІї
}

\begin{abstract}
Устименко-Косоріч О. А. Типи баянно-акордеонної школи в системі музичної освіти Сербіï.

У статті проаналізовано типи сербської баянно-акордеонної школи в контексті жанрової парадигми як складників потужної системи національної музичної освіти, яка функціонує на базі дворівневої програми - виховання компетентного фахівця суспільнонаціонального призначення (аматора) та потенційного виконавця «Високого мистецтва» засобами «узагальнення через жанр».

Ключові слова: жанрово-типологічна система музичної освіти, баянно-акордеонна
\end{abstract} школа, народна музика, класифікація, традиція, теорія.

Устименко-Косорич Е. А. Типы баянно-акордеонной школы в системе музыкального образования Сербии.

В статье проанализированы типы сербской баянно-аккордеонной школы в контексте жанровой парадигмы как составляющих элементов мощной системы национального музыкального образования, которое функционирует на базе двухуровневой программы воспитание компетентного специалиста общественно-национального назначения (любителя) и потенциального исполнителя «Высокого искусства» средствами «обобщение через жанр».

Ключевые слова: жанрово-типологическая система музыкального образования, баянно-аккордеонная школа, народная музыка, классификация, традиция, теория.

Ustymenko-Kosorich E. A. Types of accordion schools in the system of music education in Serbia.

The article analyzes the types of accordion school in Serbia in the context of genre paradigm as part of a strong national music education system. This system is functioning on the basis of a two-level programs: education of a competent specialist for social and national purposes (amateur) and a performing musician of «High Art» by means of «generalization by genre».

Key words: genre and typological system, accordion school, folk music, classification, tradition, theory.

На початку XX століття (1920р.) - у період зародження сербської баянно-акордеонної школи пріоритетним завданням музичної освіти було музичне просвітництво, залучення широкого суспільного загалу до музичного мистецтва. Але вже тоді виникали ідеї до створення відповідних навчальних закладів, які би відповідали індивідуальним потребам у підвищенні професійного виконавського рівня. У цьому сенсі в Сербії здійснюються спроби організації диференційованого виховання за ознаками підготовки майбутнього любителя або 